\title{
Inkluzja społeczna dzieci porzuconych w wybranych miastach Polski w XX i XXI wieku
}

\author{
Social inclusion of abandoned children \\ in selected towns of Poland in the 20th and 21st century
}

\begin{abstract}
The article is concerned with attempts undertaken by governmental and non-governmental organisations to eliminate the phenomenon of street children and pathological behaviours of mothers abandoning their new-born babies in various urban spaces. Materials used to present the inclusion activities on behalf of abandoned children in the
\end{abstract} $20^{\text {th }}$ and $21^{\text {st }}$ century in selected Polish towns from the social and historical perspective are historical sources excerpted from the archives, from culture-based texts (e.g. periodicals).

Keywords: children of the street, social inclusion

Inkluzyjne działania na rzecz dzieci w różnych częściach świata mają swoje tradycje. W Polsce od okresu średniowiecza odnotowywano społeczne zaangażowanie, mające na celu włączanie jednostek znajdujących się na marginesie społeczeństwa (w tym niczyich, bezdomnych dzieci). Wśród polskich instytucji dbających o wykluczonych społecznie (w tym dzieci porzuconych, sieroty ${ }^{1}$ )

1 Więcej ns temat instytucji działających na rzecz sierot na ziemiach polskich do 1918 zob. w: J. Domańska, Dobroczynność względem sierot na ziemiach polskich do 1918 roku, „Biuletyn Historii Wychowania” (2011) 27, Poznań 2012, s. 19-31. 
i niosących im pomoc można wymienić w okresie początkowym m.in. kościół, szpitale $^{2}$, w kolejnym - m.in. zakłady opieki społecznej ${ }^{3}$, fundacje, placówki dobroczynne $e^{4}$.

Ewoluowanie form i zakresu pomocy niesionej biednym, porzuconym dzieciom na przestrzeni wieków XX i XXI znalazło swe usankcjonowanie w prawie międzynarodowym, w prawie obowiązującym w poszczególnych państwach. W Polsce w okresach powojennych - po I i II wojnie światowej - zjawisko istnienia dzieci pozbawionych opieki wymuszało działania stanowiące swego rodzaju continuum wcześniejszych prac na rzecz dzieci. Rozporządzenia takie, jak: Ustawa z dnia 16 sierpnia 1923 r. o opiece społecznej5, Rozporządzenie Prezydenta Rzeczypospolitej z dnia 6 marca 1928 r. o opiekunach społecznych i o komisjach opieki społecznej ${ }^{6}$, Zarządzenie Ministra Zdrowia z dnia 17 marca 1950 r. o zaliczeniu niektórych domów matki i dziecka, domów małych dzieci oraz żłobków do zakładów społecznych służby zdrowia ${ }^{7}$, Rozporządzenie Ministra Zdrowia z dnia 18 lipca 1958 r. w sprawie zasad działalności i warunków korzystania ze świadczeń domów małych dzieci ${ }^{8}$, Rozporządzenie Ministra Sprawiedliwości z dnia 3 grudnia 1976 r. w sprawie szczególnego trybu wykonywania orzeczeń sądowych o umieszczaniu małoletniego w placówce opiekuńczo-wychowawczej ${ }^{9}$, Ustawa z dnia 27 kwietnia 2012 r. o zmianie ustawy o wspieraniu rodziny i systemu pieczy zastępczej oraz niektórych innych ustaw ${ }^{10}$ itp., wprowadzały administracyjny przydział ról w ochronie praw dzieci, zapewnieniu im opieki edukacyjnej, opiekuńczej, wychowawczej.

Niniejszy artykuł, wpisując się w obszar objęty badaniem przede wszystkim pedagogów, psychologów, socjologów, historyków, ma na celu przybliżenie z punktu widzenia historii społecznej (w tym socjohistorii ${ }^{11}$ ) eliminowania

2 Zob. np. Z. Góralski, Działalność charytatywna w Polsce przedrozbiorowej, Warszawa-Kraków 1973, s. 23-27; J. Łukaszewicz, Śpitale i inne dobroczynne zakłady i fundusze, [w:] Szpitale, red. J. Wiesiołowski, Poznań 2007, s. 19-34 (Kronika Miasta Poznania, 4); A. Grabowski, Szpitale dziewiętnastowiecznego Poznania, [w:] Szpitale, dz. cyt., s. 40-46.

3 Zob. na przykład w: R. Pacanowska, Samorzad powiatowy $w$ Wielkopolsce w latach 1919-1939, Poznań 2006, s. 204-223.

4 Zob. więcej w: M. Surdacki, Losy dzieci porzuconych w społeczeństwie europejskim do XX wieku, [w:] Dziecko w rodzinie i społeczeństwie. Dzieje nowożytne, pod red. K. Jakubiak, W. Jamrożek, Bydgoszcz 2002, s. 155-156.

5 Dz.U. $1923 \mathrm{nr} 92$ poz. 726.

6 Dz.U. 1928 nr 29 poz. 267.

7 M.P. $1950 \mathrm{nr} 33$ poz. 377.

8 Dz.U. 1958 nr 48 poz. 238.

9 Dz.U. 1976 nr 38 poz. 224.

10 Dz.U. 2012 poz. 579.

11 Zob. wnioskowanie Bronisława Geremka na temat rzeczywistości społecznej i uczestnictwa grup marginalnych w życiu społecznym i „socjalizacji” tych grup. B. Geremek, „Świat opery żebraczej”. Obraz włóczęgów i nędzarzy w literaturach europejskich XV-XVII 
przez organizacje rządowe i pozarządowe zjawiska dzieci ulicy oraz patologicznych zachowań matek w postaci porzucania przez nie noworodków w różnych przestrzeniach miejskich. Materiałami do przedstawienia inkluzyjnych działań na rzecz dzieci porzucanych w XX i XXI wieku w wybranych miastach polskich z perspektywy społeczno-historycznej będą źródła historyczne wyekscerpowane z archiwaliów (z Archiwum Archidiecezjalnego w Poznaniu, z Państwowego Archiwum w Gdańsku oddział w Gdyni, z Archiwum Państwowego w Kaliszu, z Archiwum Państwowego w Poznaniu), z tekstów kultury (np. z czasopism lokalnych, ogólnopolskich, $\mathrm{z}$ networku, sieci ${ }^{12}$ ).

Pojęcie dzieci ulicy (street children) - wywodzące się z socjologii - z założenia służy opisywaniu wykluczenia nieletnich ze społeczeństwa. Mając na względzie dobro dzieci ulicy, które przyjęło się klasyfikować w kategorie: street working children, street living children, children at risk ${ }^{13}$, można wykazać w formie opisu inkluzyjne działania na rzecz nieletnich prowadzone przez instytucje kościelne, społeczne, państwowe. Zarówno jedne, jak i drugie opisy w literaturze przedmiotu znalazły już swoje opracowania, co potwierdzają prace m.in. Barbary Adamczyk ${ }^{14}$, Urszuli Glensk ${ }^{15}$, Anity Gulczyńskiej ${ }^{16}$, Anny Kurzei ${ }^{17}$, Joanny Lustig ${ }^{18}$, Magdaleny Piątkowskiej ${ }^{19}$. Pozostają jednak luki w analizie zjawiska dzieci ulicy w różnych okresach historycznych, które w niewielkim stopniu wypełni niniejszy artykuł.

wieku, Warszawa 1989, s. 165. Zob. wypowiedź Geremka na temat badań prowadzonych przez historię społeczną z wykorzystaniem narzędzi badawczych socjologii: B. Geremek, Ludzie marginesu w średniowiecznym Paryżu XIV-XV wieku, Poznań 2003, s. 16-17.

12 E. Domańska, Wiedza o przyszłości - perspektywy na przyszłość, „Kwartalnik Historyczny" 120 (2013), s. 235.

13 Zob. charakterystykę kategorii dzieci ulicy w: Street and Working Children (1525 February 1993, Florence, Italy). Summary Report, prepared by Maggie Black, http://www. unicef-irc.org/publications/pdf/igs_streetchildren.pdf (dostęp: 30.09.2015); A. Staniszewska, Ulica nie jest dla dzieci, „Niebieska Linia”. Dwumiesięcznik poświęcony problematyce przemocy http://www.niebieskalinia.pl/pismo/wydania/dostepne-artykuly/4334-ulica-niejest-dla-dzieci (dostęp: 30.09.2015).

14 B. Adamczyk, Adaptacyjne strategie dzieci ulicy, [w:] Dzieci ulicy. Procesy marginalizacji i automarginalizacji nieletnich, pod red. K. Frysztackiego, M. Nóżki, M. Smagacz-Poziemskiej, Kraków 2011, s. 66-88.

15 U. Glensk, Przytułki dla dzieci w międzywojennej Polsce, [w:] Margines społeczny Drugiej Rzeczypospolitej, pod red. M. Rodaka, Warszawa 2013 (Metamorfozy Społeczne, 6), s. $119-138$.

16 A. Gulczyńska, Koncepcja dziecka ulicy. Analiza z perspektywy interakcyjnej, [w:] Dzieci ulicy. Procesy marginalizacji..., 2011, s. 49-65.

17 A. Kurzeja, Dzieci ulicy - profilaktyka zagrożeń, Kraków 2014.

18 J. Lustig, Skutki ubóstwa, jakich doświadczają dzieci, [w:] Ubodzy i bezdomni, pod red. P. Dobrowolskiego, Katowice 1998, s. 62-78.

19 M. Piątkowska, Życie przestępcze w przedwojennej Polsce. Gangsterzy - kasiarze brylanty, Kraków 2012, s. 356-389. 
Społeczne percypowanie ubogich - w tym dzieci porzucanych, niczyich w kulturze europejskiej od czasów wczesnochrześcijańskich warunkowało powstawanie fundacji, szpitali, przytułków, w których otaczano opieką również ${ }^{20}$ dzieci. Faktem było, że do IV wieku n.e. wspominano o dzieciach najmłodszych ${ }^{21}$. W późniejszym okresie do bez mała XI wieku ludzie nie zwracali uwagi na dzieci (i dzieciństwo $)^{22}$. Śmiertelność dzieci w tym okresie historycznym i kolejnych periodach była bardzo duża. Od XIII do XVII wieku zaczęto dostrzegać, pomimo bardzo wysokiego poziomu śmiertelności dzieci, „specyficzny charakter tych kruchych, zagrożonych istot" ${ }^{\prime 2}$ i starano się coraz intensywniej wpływać na jakość życia, wychowanie ich - zakładano przykładowo brerhotrophia, czyli przytułki dla niemowlą ${ }^{24}$, prototypy domu dziecka - oddziały dla dzieci z nauką rzemiosła w szpitalach i przytułkach ${ }^{25}$. W w 1736 roku z inicjatywy Gabriela P. Boduena założono w Warszawie pierwszy na ziemiach polskich zakład opiekuńczy („szpital dla przyjmowania i wychowywania niemowląt”, zwany Domem Podrzutków), przeznaczony tylko dla dzieci ${ }^{26}$. W XIX wieku dziecko zaczynało być dostrzegane, dla niego powoli, ale systematycznie starano się organizować prawo, dostosowywać zadania do jego rozwoju ${ }^{27}$. Z myślą o niepełnoletnich zaczęto tworzyć pierwsze ochronki (w 1837 roku w Warszawie powołano do życia pierwszą w Polsce ochronkę $e^{28}$ ), zakłady wychowawcze (w Prusach Fryderyk W. Froebel założył w 1837 roku zakład wychowawczy w Blankenburgu ${ }^{29}$ ), sierocińce (w Galicji w 1830 roku powstał sierociniec utworzony przez Polskie Towarzystwo Dobroczynne ${ }^{30}$ ).

20 W czasach starożytności chrześcijańskiej i później w okresie średniowiecza odnotowywano działania na rzecz ubogich. Zaczynały w tych okresach historycznych powstawać pierwsze szpitale, przytułki, takie jak: szpital-przytułek Sain-Jacques-du-Haut-Pas w Paryżu, przytułek Sainte-Avoie w Paryżu. W początkowym okresie funkcjonowania szpitale pełniły funkcje pewnego rodzaju przytułków dla „ubogich, starców, ludzi chorych, zniedołężniałych, osieroconych dzieci, podrzutków”. Zob. S. Lipiński, Zakłady dobroczynne i domy poprawny w dawnej Polsce, Łódź 2010, s. 9. Por. B. Geremek, Ludzie marginesu ..., dz. cyt., s.145.

21 P. Aries, Historia dzieciństwa, przekł. M. Ochab, Warszawa 2010, s. 19.

22 P. Aries, Historia dzieciństwa, dz. cyt., s. 59.

23 P. Aries, Historia dzieciństwa, dz. cyt., s. 69-70.

24 S. Lipiński, Zakłady dobroczynne i domy poprawny $w$ dawnej Polsce, Łódź 2010, s. 9.

25 J. Raczkowski, Dom dziecka, [w:] Encyklopedia pedagogiczna, pod red. W. Pomykały, Warszawa 1997, s. 117.

26 J. Raczkowski, Dom dziecka, dz. cyt., s. 117.

27 J. Domańska zauważa, że pod koniec XIX i na początku XX wieku na ziemiach polskich w środowiskach społecznych wzrastało zainteresowanie sprawami opieki nad dzieckiem. Zob. J. Domańska, Dobroczynność względem sierot..., dz. cyt., s. 30-31.

28 B. Wigocka-Okoń, Przedszkole, [w:] Encyklopedia pedagogiczna, dz. cyt., s. 636-637.

29 B. Wigocka-Okoń, Przedszkole, dz. cyt., s. 637.

30 C. Kępski, Idea miłosierdzia a dobroczynność i opieka, Lublin 2002, s. 107-111. 
Dwudziestowieczne uwarunkowania - bezpośrednio po I wojnie światowej spowodowały, że nowo odrodzone państwo polskie w swym ustawodawstwie musiało uwzględnić instytucje działające na rzecz dzieci porzuconych, osieroconych itp. (zob. powyżej wymienione ustawy i rozporządzenia). Na terenie II Rzeczypospolitej Polskiej opiekę sprawowały, oprócz usankcjonowanych prawnie instytucji będących pod bezpośrednią kuratelą opieki społecznej ${ }^{31}$ (np. Dom Sierot dla Chłopców przy Tadeusza Kościuszki w Kaliszu ${ }^{32}$, Dom Sierot w Szamotułach ${ }^{33}$, Ochronka Powiatowa ${ }^{34}$, Miejski Sierociniec ${ }^{35}$, Przytułek dla Sierot ${ }^{36}$, Zakład Sierót w Wolsztynie ${ }^{37}$ ), instytucje działające pod auspicjami związków wyznaniowych ${ }^{38}$ (np. Dom Sierót im. Jadwigi we Wronkach ${ }^{39}$, Dom Sierot pod Szamotułami ${ }^{40}$, Ochronka Dzieci Chrześcijańskich w m. Błaszki ${ }^{41}$, Ewangelickie Schronisko dla Dzieci ${ }^{42}$ ), zgromadzenia zakonne (np. Ochronka S.S. Elżbietanek ${ }^{43}$, Żłóbek Kwestarek ${ }^{44}$ ) itp. ${ }^{45}$. Te ostatnie, czyli prowadzone

31 Własność poszczególnych instytucji została uwzględniona w wybranych zestawieniach statystycznych. Przykładowy podział stacji opieki nad matką i dzieckiem jako własność państwa, samorządu, ubezpieczalni społecznych, organizacji społecznych zawiera Tabela 9. Sieć stacyj opieki nad matka i dzieckiem w Polsce w latach 1933-1936, „Mały Rocznik Statystyczny" 7 (1936), s. 202.

32 Archiwum Państwowe w Kaliszu, Wydział Powiatowy w Kaliszu [dalej: APK, WPK], sygn. 512, Domy ludowe, przytułki i ochronki.

33 Archiwum Państwowe w Poznaniu [dalej: APP], Miejski Urząd Bezpieczeństwa i Porządku Publicznego, sygn. 73, Zakłady opiekuńcze - Dom Jadwigi.

34 Archiwum Państwowe w Gdańsku oddział w Gdyni, Starostwo Morskie w Wejherowie, sygn. 48, Opieka nad dziećmi.

35 Archiwum Państwowe w Poznaniu, Akta miasta Poznania [dalej: AmP], sygn. 4032, Miejski Sierociniec.

36 APP, AmP, sygn. 3980, Statystyka. Opieka nad ubogimi.

37 APP, AmP, sygn. 546, Miejski Urząd Policyjny.

38 W Poznaniu w roku 1919 sprawowały opiekę nad niepełnoletnimi, ze szczególnym uwzględnieniem sierot i dzieci nieślubnych, towarzystwa: Towarzystwo Opieki nad Dziećmi Katolickimi, Ewangelickie Stowarzyszenie Wychowawcze na obszar Księstwa Poznańskiego, zob. w: APP, AmP, sygn. 4033, Towarzystwo opieki nad dziećmi katolickiemi w Poznaniu.

39 Dom Sierot założony został w 1895 roku, stanowił fundację ks. Grabowskiego, własność parafii wroneckiej. Celem jego działalności było wychowywanie sierot i prowadzenie ochronki dla miejscowych dzieci. Zob. APP, Miejski Urząd Bezpieczeństwa i Porządku Publicznego, sygn. 73, Zakłady opiekuńcze - Dom Jadwigi.

40 Dom Sierot był w zarządzie Sióstr Franciszkanek Rodziny Marii. W 1927 roku wychowywało się w nim „140 sierot z Wielkopolski i z kresów”, Szamotuły (Dom Sierot), „Gazeta Międzychodzka” 6 II 1927, nr 15, s. 3.

41 APK, WPK, sygn. 512, Domy ludowe, przytułki i ochronki.

42 APP, AmP, sygn. 3980, Statystyka. Opieka nad ubogimi.

43 APP, AmP, sygn. 3980, Statystyka. Opieka nad ubogimi.

44 APP, AmP, sygn. 3980, Statystyka. Opieka nad ubogimi.

45 Przykładowo w roku 1934 zakłady opieki zamkniętej dla dzieci i młodzieży były własnością: samorządów terytorialnych (w tym Skarbu Śląskiego), organizacji społecznych, 
przez zgromadzenia i związki wyznaniowe, Zarządzeniem Ministra Zdrowia z dnia 17 marca 1950 r. zostały przejęte przez państwo. Od 1950 roku zostały zaliczone do zakładów społecznych służby zdrowia: żłobki Zrzeszenia „Caritas” m. st. Warszawy, Stowarzyszenia Pań Miłosierdzia w Świeciu, Zrzeszenia „Caritas” w Międzyrzeczu, Fundacji Zakładu Św. Anny, Zgromadzenia ss. Józefitek w Kluczborku itp.; domy małych dzieci Zgromadzenia ss. Szarytek w Chełmnie, Zgromadzenia ss. Serafitek w Poznaniu, Zgromadzenia ss. św. Wincentego à Paulo w Gnieźnie, Zgromadzenia SS. Elżbietanek w Prudniku itp. ${ }^{46}$.

Działalność poszczególnych instytucji przeznaczonych dla dzieci wpisywała się w programy wychowawcze, opiekuńcze, społeczne obowiązujące na terenie II RP, Rzeczypospolitej Polskiej Ludowej, czy III Rzeczypospolitej Polskiej ${ }^{47}$, a swe wytyczne lub odpowiedniki, szczególnie w XXI wieku, miała m.in. w programach europejskich (ustaleniach np. Ligi Narodów), programach unijnych, oenzetowskich, UNICEF-u. W okresie dwudziestolecia była nastawiona na zapewnienie opieki sierotom wojennym, podrzutkom, dzieciom parającym się drobnym handlem, prostytuującym się, żebrzącym; a także na prowadzenie działań resocjalizujących w celu wydobycia dzieci ze środowisk patogennych. Bezpośrednio po II wojnie światowej pomoc była kierowana przede wszystkim do dzieci będących sierotami (początkowo przede wszystkim do sierot wojennych), pozbawionymi środków do życia. Pod koniec XX i z początkiem XXI wieku szczególne działania adresowano do dzieci ulicy, do których przyjęło się zaliczać dzieci zarabiające na swoje rodziny (np. młodzi żebrzący ${ }^{48}$ ), dzieci będące ofiarami handlu żywym towarem (np. żebrzące dzieci, wykorzystywane w celach nierządnych), dzieci osierocone, porzucone - muszące

zgromadzeń zakonnych, związków wyznaniowych, fundacji, osób prywatnych, zob. Tabela 5. Zakłady opieki zamkniętej w Polsce według właścicieli w 1934 r., „Mały Rocznik Statystyczny" 7 (1936), s. 203.

46 Zob. Załącznik do zarządzenia Ministra Zdrowia z dn. 17 marca 1950 r. (poz. 377), M.P. $1950 \mathrm{nr} 33$ poz. 377.

47 Przykładowe programy pomocowe - Rządowy program pomocy dzieciom i uczniom $\mathrm{w}$ formie zasiłku losowego na cele edukacyjne, pomocy uczniom $\mathrm{w}$ formie wyjazdów terapeutyczno-edukacyjnych oraz pomocy dzieciom i uczniom w formie zajęć opiekuńczych i zajęć terapeutyczno-edukacyjnych w 2015 r. z dn. 5 sierpnia 2015 r. (Dz.U. 2015, poz. 1103); Program Dzieci Ulicy (program realizowany przez Fundację dla Polski), http://www.fdp.org.pl/program-dzieci-ulicy; Program „Dzieci Ulicy” realizowany przez Ośrodek Pomocy Społecznej w Gliwicach, http://opsgliwice.bnet.pl/index.php/publisher/ articleview/frmArticleID/138/; W. Falk, Pomoc urwisom - Dzieci ulicy, [w:] Diakonia Kościoła Ewangelicko-Augsburskiego, http://www.diakonia.org.pl/index.php?D=105 (dostęp: 2.10.2015).

48 Zob. przykładową notkę prasową: Żebracy symulanci, „Kurjer Wileński” 19 VI 1936, nr 167, s. 9. 
same zadbać o swoją egzystencję, dzieci wychowywane przez ulicę - niestroniące od używek, wchodzące w środowiska przestępcze.

Inkluzyjne działania na rzecz dzieci porzuconych, osieroconych w okresie bez mała stuletnim pod pewnymi względami ewoluowały. Obok stałych instytucji opiekuńczych, fundacji, które swoje działania skupiały na pomocy nieletnim, włączaniu ich do struktur społecznych czy też przeprowadzaniu loteriii ${ }^{49}$, z których dochód był przeznaczony na konkretne instytucje opiekuńcze ${ }^{50}$, czy zbiórek żywności, datków ${ }^{51}$ itp., pojawiły się nowe formy - w szerszy sposób oddziałujące na ludzi poprzez wykorzystanie technologii cyfrowych, internetu, mass mediów itp. Coraz częstszymi formami pozyskiwania funduszy, realnej pomocy na rzecz dzieciom ulicy stały się akcje medialne (spoty obrazujące życie dzieci niczyich itp.), zbiórki pieniędzy za pomocą np. SMS-ów.

Wśród instytucji wpływających na inkluzyjność społeczną dzieci niczyich, pozostawionych samym sobie, porzucanych można wymienić: domy małego dziecka (sierocińce), przytułki dla dzieci i młodzieży nieletnich, rodziny zastępcze (rodzinne domy dziecka). Te typy instytucji tworzono w dwudziestoleciu międzywojennym (jak i wcześniej) w postaci izb dziecka (np. Izba Zatrzymań dla Nieletnich w Poznaniu ${ }^{52}$ ), domów matki i dziecka ${ }^{53}$ (Miejski Dom dla Matki i Dziecka ${ }^{54}$, Miejski Dom Wychowawczy w Łodzi ${ }^{55}$, Miejska Stacja Opieki nad Matką i Dzieckiem w Mysłowicach, Stacja Opieki nad Matka i Dzieckiem Czerwonego Krzyża w Poznaniu ${ }^{56}$, Stacja Opieki nad Matką i Dzieckiem w Sza-

49 Jedną $z$ form pomocy ubogim dzieciom, sierotom stanowiły zapomogi przyznawane tym ostatnim przez zakłady pracy. Zob. informację na temat zapomóg gwiazdkowych dla wdów i sierot po pracownikach kolejowych, „Gazeta Pleszewska” 22 X 1933, nr 85, s. 4.

50 Zorganizowanie loterii fantowej Stacji Opieki nad Matka i Dzieckiem w Szamotułach, „Gazeta Międzychodzka” 30 I 1927, nr 13, s. 3.

51 W apelu o pomoc dla dzieci zapisano m.in.: „Kto ma zapasy jabłek, orzechów z własnego ogrodu, niechaj cząstkę udzieli najbliższej Ochronce, stare ubranka, buciki będą z wdzięcznością przyjęte”, $\mathrm{Na}$ „Gwiazdkę” dla polskich Ochronek, „Gazeta Lwowska” 12 XII 1923,277 , s. 5.

52 Izba ta została otwarta z początkiem 1938 roku. Funkcjonowała na terenie parafii Bożego Ciała w Poznaniu. Zob. „Dziennik Poznański” 1938, nr 26, s. 6.

${ }^{53} \mathrm{~W}$ materiałach źródłowych pojawia się określenie „stacja opieki nad matką i dzieckiem”. Zob. np. Tabelę 9 Sieć stacyj opieki nad matką i dzieckiem w Polsce w latach 19331936, „Mały Rocznik Statystyczny” 7 (1936), s. 204.

54 W listopadzie 1935 roku uruchomiono przytułek publiczny - mający być tymczasowym schronieniem dla ubogich, bezdomnych matek z nieletnimi dziećmi. Zob. pismo z 19 XI 1935, w: APP, AmP, sygn. 4110, Dom dla matki i dziecka.

55 Zob. więcej w: A. Bołdyrew, J. Sosnowska, Troska o dziecko i jego potrzeby $w$ działaniach Wydziału Opieki Zarządu Miasta Łodzi w okresie międzywojennym, „Kultura i Wychowanie" (2014) nr 8, s. 21-34.

56 APP, AmP, sygn. 11007, Sprawozdania z działalności Stacji opieki nad matka i dzieckiem. 
motułach ${ }^{57}$ ), schronisk dla dzieci (Schronisko Dzieciątka Jezus na św. Wojcie$\mathrm{chu}^{58}$, Schronisko dla Dzieci z Repatriacji w Płocku ${ }^{59}$ ), żłobków zamkniętych (Żłóbek im. A. Balińskiego w Wągrowcu ${ }^{60}$ ), zakładów poprawy (Zakład św. Anny w Kamieniu Pomorskim, pow. Sępólno ${ }^{61}$ ) itp. Te typy ośrodków pomocowych w większości działały (przede wszystkim żłóbki, przytułki, domy małego dziecka, domy sierot, po kilkudziesięcioletniej przerwie rodziny zastępcze ${ }^{62}$ ) po II wojnie światowej i działają do początku XXI wieku.

Grupy zjawisk społecznych negatywnie oddziałujących na życie dziecka i jego psychofizyczny rozwój (porzucanie noworodków, dzieci w wieku przedszkolnym przez matki, kidnapingu dzieci, handel dziećmi itp.) wpływały i wpływają w bezpośredni sposób na działania społeczne na rzecz dzieci, których życie i rozwój były i są zagrożone w poszczególnych okresach historycznych (z uwzględnieniem przede wszystkim czasu: wojen, pokoju, kryzysu światowego, jak i obecności w poszczególnych częściach świata biedy i niedoli społecznej ${ }^{63}$ ). Niepokojące zjawiska społeczne, takie jak: porzucanie narodzonych dzieci, nieletnich dzieci w różnych przestrzeniach miejskich przede wszystkim przez matki, jak również wzrost liczby dzieci nieślubnych i ich śmiertelnośćc ${ }^{64}$, w latach 1918-1939 w Polsce

${ }^{57}$ Stacja Opieki nad Matka i Dzieckiem w Szamotułach, „Gazeta Międzychodzka” 17 XII 1926, nr 145, s. 2.

58 APP, AmP, sygn. 3969, Polsko-Amerykański Komitet Pomocy Dzieciom.

59 APP, AmP, sygn. 4032, Miejski Sierociniec.

60 APP, Wydział Powiatowy, sygn. 39, Wagrowiec.

61 APP, AmP, sygn. 546, Miejski Urząd Policyjny.

62 W roku 1958 powstały rodzinne domy dziecka - Dowlaszów w Szczecinie i Zapartów w Świdwinie. Na mocy ustaw z 1975 roku (nowelizacja Kodeksu rodzinnego i opiekuńczego z dn. 19 grudnia 1975), rozporządzenie z 1979 roku (Rozporządzenia Rady Ministrów z dnia 26 stycznia 1979 r.), ustawy z 2004 roku (Ustawy z dnia 12 marca 2004 r. o pomocy społecznej) instytucja rodziny zastępczej została przywrócona i swymi działaniami wpisuje się w inkluzję dzieci porzuconych, osieroconych. Por. M. Prokosz, Dziecko osamotnione i sieroce. Między rodzina pochodzenia a rodzinna forma opieki, [w:] Człowiek w sytuacji (bez)nadziei konteksty teoretyczne i praktyczne, pod red. R. Bilik i A. Urbanka, Legnica 2011, s. 14.

${ }^{63}$ Zygmunt Bauman, opierając się na przekazach medialnych, zwraca uwagę na niewystarczającą pomoc przeznaczoną na cele społeczne. Stwierdza, że „3/4 rodzin na całym świecie i 90\% rodzin w Afryce nie może liczyć na jakąkolwiek formę takiej pomocy”. Przywołuje inicjatywę z lipca 2010 roku Organizacji Narodów Zjednoczonych - prowadzenia kampanii „na rzecz objęcia systemem opieki społecznej także tych części świata, w których do tej pory on nie istniał", aby wskazać niewystarczającą liczbę działań i pomocy faktycznej okazywanej masom biednych świata. Zob. Z. Bauman, 26 grudnia 2010. O resocjalizacji socjalności, [w:] Z. Bauman, To nie jest dziennik, przekł. M. Zawadzka, Kraków 2012, s. 153-154.

${ }^{64} \mathrm{~W}$ jednym z dokumentów z 1923 roku zapisano: „mnożą się wypadki podrzucania niemowląt $\mathrm{w}$ ostatnich czasach wprost $\mathrm{w}$ zastraszający sposób i rośnie śmiertelność pomiędzy dziatwą nieślubną. W ubiegłym roku musieliśmy się mniej więcej 100 podrzutkami zająć i odczuwamy obawę, że i w roku bieżącym stan rzeczy się nie poprawi”. Zob. Pismo 
wymusiły szereg działań o charakterze społeczno-opiekuńczym. Funkcjonujące od lat instytucje społeczne, kościelne, wyznaniowe kontynuowały działania w ramach swych statutów (np. prowadzone przez Towarzystwo Opieki nad Dziećmi Katolickimi - Dom Sierót w Gnieźnie, Dom Sierót w Ostrowie ${ }^{65}$, Dom Sierot im. Jadwigi we Wronkach ${ }^{66}$, Zakład SS Salezjanek w Wilnie ${ }^{67}$ ). Powstające w miarę zapotrzebowań społecznych nowe ośrodki zapewniające pomoc nieletnim w okresie dwudziestolecia międzywojennego ${ }^{68}$ korzystały ze wsparcia państwa (samorządów, budżetu Ministerstwa Opieki Społecznej ${ }^{69}$ ). Liczby dzieci porzucanych w różnych przestrzeniach miejskich ${ }^{70}$ były znaczne, na co wskazują informacje z dzienników (zob. tabelę nr 1), informacje zawarte w dokumentacji szpitalnej czy policyjnej ${ }^{71}$. Wśród powodów porzucania dzieci (niemowląt) można przede wszystkim wymienić fakt posiadania nieślubnego dziecka przez matkę, biedę matki (względnie rodziców dziecka), załamanie psychiczne matki (najczęściej po porodzie).

Tabela nr 1. Przykłady porzucania dzieci w II RP

\begin{tabular}{|c|c|l|}
\hline $\begin{array}{c}\text { Nazwa } \\
\text { czasopisma }\end{array}$ & $\begin{array}{c}\text { Data } \\
\text { (miesiąc, rok) }\end{array}$ & \multicolumn{1}{c|}{$\begin{array}{c}\text { Miejsce porzucenia niemowlęcia/ } \\
\text { nieletniego dziecka }\end{array}$} \\
\hline „Gazeta Lwowska”a & styczeń 1924 & noworodek porzucony w okolicach Lwowa \\
\hline „Kurier Poznański”b & maj 1925 & $\begin{array}{l}\text { niemowlę w domu przy ul. Sapieżyńskiego 3 } \\
\text { w Poznaniu }\end{array}$ \\
\hline „Kurier Poznański”c & maj 1925 & $\begin{array}{l}\text { niemowlę (dziesięciodniowe dziecko) pod } \\
\text { murem przy ul. Gwarnej w Poznaniu }\end{array}$ \\
\hline
\end{tabular}

z dn. 14 V 1923, w: APP, AmP, sygn. 4111, Założenie przytuliska dla dziatwy przedszkolnej w pałacu naramowickim.

65 Archiwum Archidiecezjalne w Poznaniu, KA 15029, Akta opieki nad dziećmi.

66 APP, Miejski Urząd Bezpieczeństwa i Porządku Publicznego, sygn. 73, Zakłady opiekuńcze - Dom Jadwigi.

${ }^{67}$ Zgodnie z ustaleniami Zarządu Miasta Wilna podrzutki miały być kierowane do Przytułku Dzieciątka Jezus i do Zakładu SS. Salezjanek. Zob. „Kurier Wileński” 19 VI 1936, nr 167, s. 9.

68 Historia Miejskiego Przytuliska dla Niemowląt w Poznaniu, zob. w: APP, AmP, sygn. 4111, Założenie przytuliska dla dziatwy przedszkolnej w pałacu naramowickim.

69 Zob. przykładowe wydatki w: Tabela 1. Wydatki budżetu Ministerstwa Opieki Spotecznej na opiekę społeczna w Polsce w latach 1928/29 - 1936/37, „Mały Rocznik Statystyczny" 7 (1936), s. 201; Tabela 1 Wydatki z budżetu Ministerstwa Opieki Społecznej na opieke społeczną, „Mały Rocznik Statystyczny” 10 (1939), s. 287.

70 Zdarzały się również porzucenia dzieci na wsiach.

71 Chłopiec o imieniu Paweł, który został porzucony przy ul. Dąbrowskiego 33 w Poznaniu, w wieku 17 dni życia zmarł w Szpitalu Miejskim. Zob. Dokument śmierci, w: APP, AmP, sygn. 11008, Dzieci podrzucone (podrzutki). 


\begin{tabular}{|c|c|c|}
\hline $\begin{array}{c}\text { Nazwa } \\
\text { czasopisma }\end{array}$ & $\begin{array}{c}\text { Data } \\
\text { (miesiąc, rok) }\end{array}$ & \multicolumn{1}{|c|}{$\begin{array}{c}\text { Miejsce porzucenia niemowlęcia/ } \\
\text { nieletniego dziecka }\end{array}$} \\
\hline „Gazeta Pleszewska"d & luty 1928 & podrzutek pozostawiony w ustępie (Pleszew) \\
\hline „Dziennik Bydgoski”e & czerwiec 1931 & $\begin{array}{l}\text { niemowlę (chłopiec w 3 dniu życia) w podwó- } \\
\text { rzu domu nr 39 przy śmietniku przy ul. Pół- } \\
\text { wiejskiej w Poznaniu }\end{array}$ \\
\hline „Rekord Polski”f & styczeń 1932 & $\begin{array}{l}\text { niemowlę 10-dniowe w bramie przy } \\
\text { Grochowskich Łąkach 5 w Poznaniu }\end{array}$ \\
\hline „Gazeta Lwowska"g & sierpień 1935 & $\begin{array}{l}\text { trzyletnie dziecko porzucone w bramie przy } \\
\text { ul. Sykstuskiej 32 we Lwowie }\end{array}$ \\
\hline „Kurier Wileński”h & lipiec 1939 & $\begin{array}{l}\text { dziewczynka 4-miesięczna porzucona przy } \\
\text { ul. Wielkiej 30 w Wilnie }\end{array}$ \\
\hline
\end{tabular}

\section{PRZYPISY}

a Aresztowanie pod zarzutem porzucenia noworodka, „Gazeta Lwowska” 11 I 1924, nr 9, s. 5.

b „Kurier Poznański” 6 V 1925, nr105, s. 5.

c „Kurier Poznański” 31 V 1925, nr 126, s. 5.

d „Gazeta Pleszewska” 2 II 1928, nr 10, s. 4.

e „Dziennik Bydgoski” 28 VI 1931, nr 147, s. 9.

f "Rekord Polski” 4 I 1932, nr 4, s. 2.

g "Gazeta Lwowska” 31 VIII 1935, nr 198, s. 2.

h „Kurier Wileński” 1 VII 1939, nr 179, s. 8.

Źródło: Gazety codzienne okresu 1924-1939.

Zestawienia statystyczne zgromadzone w Małym Roczniku Statystycznym potwierdzają istnienie wyżej wymienionych zjawisk. Przykładowo dzieci nieślubnych urodzonych w latach 1929-1931 w Polsce odnotowano 58 tys., co stanowiło 5,9 proc. ogółu urodzeń, zaś w latach 1931-1932 w Polsce odnotowano 57 tys., co stanowiło 6 proc. ogółu urodzeń. Najwięcej urodzeń żywych nieślubnych dzieci odnotowano we wskazanych okresach w województwach południowych (w obu okresach) - 20 tys. oraz w centralnych (w obu okresach) - 19 tys. W województwach zachodnich odnotowano 11 tys. nieślubnych dzieci w latach 1929-1931 i 10 tys. w latach 1931-1932, a we wschodnich (w obu okresach) 8 tys. $^{72}$ nieślubnych dzieci.

Liczby nieletnich pozostających bez opieki - całkowitej, częściowej wymusiły wyodrębnienie zakładów opiekuńczych, zgodnie z obowiązującymi

72 Tabela 5. Urodzenia żywe w Polsce w latach 1929-1931, „Mały Rocznik Statystyczny” 7 (1936), s. 26; Tabela 10. Urodzenia żywe. Przeciętne roczne w latach 1931-1932, „Mały Rocznik Statystyczny” 10 (1939), s. 47. 
podziałami na: zakłady zamknięte, w których dzieci mieszkają na stałe (domy wychowawcze - zakłady dla niemowląt i dzieci do lat 3; schroniska - zakłady dla dzieci w wieku 3-7 lat; pogotowania opiekuńcze - zakłady, które zapewniają dzieciom pozbawionym opieki czasowego schronienia, celem późniejszego umieszczenia ich $\mathrm{w}$ odpowiednim zakładzie wyżej wskazanym $^{73}$ ), zakłady półotwarte, w których dzieci spędzają część dnia (żłob$\mathrm{ki}^{74}$ - zakłady dla niemowląt i dzieci do 3 lat; ochronki - zakłady dla dzieci w wieku 3-7 lat (zajęcia przed południem); świetlice lub kluby - zakłady dla uczącej się młodzieży (po południu); sale zajęć lub izby rzemieślnicze dla młodzieży - zakłady dla młodzieży przygotowującej się do zawodu ${ }^{75}$ ), zakłady otwarte, w których dzieci otrzymują tylko pomoc doraźną (poradnie, kuchnie itp. $)^{76}$. Biorąc pod uwagę powyższy podział, można podać liczby sierot - podopiecznych zakładów opieki zamkniętej w Polsce. Przykładowo w roku 1935 odnotowano ich w takich zakładach 8556, w roku $1937-8203^{77}$. Statystyka zachowana $\mathrm{z}$ tego okresu historycznego (nadto) potwierdza istnienie zakładów, stacji sprawujących kuratelę nad nieletnimi pozostawionymi bez opieki. Przykładowo w roku 1934 funkcjonowało na terenie Polski 46 żłobków, w tym w województwach centralnych 16 , zachodnich -15 , południowych -10 , wschodnich $-5^{78}$. W 1935 roku na terenie II RP działały 44 żłobki oraz domy matki z dzieckiem, a w roku

73 Zob. Okólnik w przedmiocie ustalenia nazw zakładów opiekujących się dziećmi wydany przez Wojewodę Poznańskiego dn. 9 listopada 1923 r., w: APP, Miejski Urząd Bezpieczeństwa i Porządku Publicznego, sygn. 73, Zakłady opiekuńcze - Dom Jadwigi.

74 Istniały na terenie Polski różne typy żłobków, w tym żłobki dla niemowląt przy fabrykach. Były one organizowane przez przedsiębiorcę zgodnie z Rozporządzeniem Ministra Pracy i Opieki Społecznej z dn. 11 marca 1927 r. w sprawie urządzania i utrzymywania żłobków dla niemowląt w zakładach pracy. Zob. komentarz w: Żłobki dla niemowląt w fabrykach, „Polska Zachodnia”, 25 IV 1927, nr 94 - 20/24, s. 3. Przykładowo na terenie II RP w poszczególnych województwach w roku 1938 działały żłobki: w województwach centralnych -18 , w zachodnich -9 , w południowych -5 , we wschodnich nie odnotowano żadnego. Odnotowano w nich następujące liczby dzieci: w województwach centralnych -279 , w zachodnich -122 , w południowych -55 . Zob. tabelę Przyfabryczne instytucje ochrony macierzyństwa, „Mały Rocznik Statystyczny” 10 (1939), s. 292.

75 Okólnik w przedmiocie ustalenia nazw zakładów opiekujących się dziećmi wydany przez Wojewodę Poznańskiego dn. 9 listopada 1923 r., w: APP, Miejski Urząd Bezpieczeństwa i Porządku Publicznego, sygn. 73, Zakłady opiekuńcze - Dom Jadwigi.

76 Okólnik w przedmiocie ustalenia nazw zakładów opiekujących się dziećmi wydany przez Wojewodę Poznańskiego dn. 9 listopada 1923 r., dz. cyt.

77 Tabela 6. Zakłady opieki całkowitej (zamkniętej) dla dzieci i młodzieży, „Mały Rocznik Statystyczny" 10 (1939), s. 289.

78 Tabela 4. Zakłady opieki zamkniętej w Polsce według charakteru zakładów w 1934 r., „Mały Rocznik Statystyczny” 7 (1936), s. 202. 
1937 - 3979. Stacji opieki nad matką i dzieckiem w Polsce było np. w roku 1933 - 235, w 1934 - 235, w 1935 - 229, w roku 1936 - $233^{80}$.

Osobną formę inkluzji dzieci obok żłobków zamkniętych, sierocińców (domów sierot) stanowiły rodziny zastępcze. Faktem było to, iż przed I wojną światową niemowlęta i sieroty na ziemiach polskich (znajdujących się pod zaborami) umieszczano z „łatwością u rodzin miejskich i pozamiejskich” ${ }^{81}$. Akcje wysyłania dzieci na wieś do rodzin zastępczych ${ }^{82}$ (rodzin opiekuńczych) określanych mianem „gniazda sierocego”, „wioski kościuszkowskiej”, zgodnie z założeniami ich prekursora - Kazimierza Jeżewskiego, zainicjowane z początkiem XX wieku (pierwszy rodzinny dom dziecka powstał w Stanisławczyku pod Przemyślem w roku $1908^{83}$ ) trwały do 1939 roku $^{84}$, co potwierdzały akcje prowadzone na rzecz dzieci niczyich przez różne organizacje, np. przez Pomorskie Towarzystwo Opieki nad Dziećmi ${ }^{85}$, które umieszczały dzieci w „,rodzinach miłosiernych” ${ }^{\text {86 }}$. W skazane działania na rzecz opieki nad sierotami, podrzutkami w postaci funkcjonowania

79 Tabela 6. Zakłady opieki całkowitej (zamkniętej) dla dzieci i młodzieży, „Mały Rocznik Statystyczny" 10 (1939), s. 289.

${ }^{80}$ Tabela 9. Sieć Stacyj opieki nad matka i dzieckiem w Polsce w latach 1933-1936, „Mały Rocznik Statystyczny” 7 (1936), s. 202.

81 Referat $\mathrm{w}$ sprawie urządzania miejskiego przytuliska dla niemowląt $\mathrm{w}$ pałacu naramowickim, w: APP, AmP, sygn. 4111, Założenie przytuliska dla dziatwy przedszkolnej $w$ pałacu naramowickim.

82 Jedną $\mathrm{z}$ orędowniczek idei umieszczania dzieci w rodzinach zastępczych była Wanda Szuman. Zob. jej wypowiedź z lat trzydziestych ubiegłego wieku, w: W. Szuman, System umieszczania sierot $w$ rodzinach, Poznań 1931. Na temat Wandy Szuman i innych wybitnych pedagogów dążących do zapewniania opieki nad dziećmi będącymi sierotami, dziećmi porzuconymi w rodzinach zastępczych zob. W. Theiss, Pomorskie Towarzystwo Opieki nad Dziećmi 1918-1948, „Rozprawy z Dziejów Oświaty” 36 (1994), s. 180-181.

${ }_{83}$ Por. W. Jamrożek, Problematyka opieki nad dzieckiem na kongresach i zjazdach pedagogicznych $w$ Polsce do 1939 roku, [w:] Kongresy i zjazdy pedagogiczne w Polsce w XX wieku, pod red. A. Kicowskiej, Toruń 2001, s. 123.

84 M. Prokosz, Dziecko osamotnione i sieroce. Między rodzina pochodzenia a rodzinna forma opieki, [w:] Człowiek w sytuacji (bez)nadziei - konteksty teoretyczne i praktyczne, pod red. R. Bilik i A. Urbanka, Legnica 2011, s. 14.

85 W latach 1918-1919 dzięki staraniom Pomorskiego Towarzystwa Opieki nad Dziećmi wysłano na wieś na czas wakacji ponad 300 dzieci. Cel, jaki przyświecał temu działaniu, był następujący: „chodziło zarówno o ogólne wzmocnienie zdrowia i sił najmłodszego pokolenia, osłabionego przez trudne wojenne lata, jak i kontakt z polską tradycją i kulturą. Z możliwości tych skorzystały sieroty wojenne, bezdomne dzieci oraz dzieci z biednych rodzin $\mathrm{z}$ Torunia i okolic". Zob. W. Theiss, Pomorskie Towarzystwo Opieki nad Dziećmi..., dz. cyt., s. 177.

${ }^{86} \mathrm{~W}$ czasopiśmie z okresu dwudziestolecia międzywojennego pisano przykładowo: „W rodzinach poleconych przez miejscowych księży proboszczów na prowincji, umieszczane są starsze dziewczynki, które ukończyły szkołę; uczą się tam gospodarstwa domowego, mniejsze zaś dzieci oddawane są rodzinom bezdzietnym, które biorą je jako własne”. Zob. „Pielgrzym” 1926, nr 46. 
wielodzietnych, zastępczych rodzin na niektórych terenach II RP nie przynosiły zamierzonych skutków. Po wielkiej wojnie zaobserwowano spadek zainteresowania sprawowaniem opieki przez rodziny, które już tę opiekę wcześniej ofiarowały, jak i wśród rodzin, które mogły takiej opieki udzielić. Ze względów finansowych, wynikających ze „stosunków gospodarczych i zarobkowych" ${ }^{87}$ rodziny miejskie i pozamiejskie odmawiały przyjmowania dzieci za opłatą. Zaledwie niewielka liczba rodzin (szczególnie miejskich), wśród których nie wszystkie się do tego,,nadawały”, zgłaszała chęć przyjęcia dzieci osieroconych, porzuconych na wychowanie. Zdarzały się przypadki, że zgłaszające się do opieki nad dziećmi niczyimi rodziny żądały zbyt wysokich sum, których, jak to zostało odnotowane w Poznaniu, „miasto przyznać” 88 nie mogło z braku wystarczających funduszy.

Idea, która przyświecała tworzeniu rodzin zastępczych z początku XX wieku, na początku kolejnego wieku trafiła na podatny grunt. Zgodnie z Ustawą z dnia 9 czerwca 2011 r. o wspieraniu rodziny i systemie pieczy zastępczeje ${ }^{89}$ zaczęto określać na nowo zasady funkcjonowania rodzin zastępczych, rodzinnych domów dziecka (Dział III Piecza zastępcza, Rozdział 2 Rodzinna piecza zastępcza art. 39-92). Współcześnie można wskazać istniejące w różnych częściach Polski rodziny zastępcze. Niektóre z nich wchodzą w skład stowarzyszeń rodzicielstwa zastępczego. Przykładowo na stronie Podkarpackiego Stowarzyszenia Rodzicielstwa Zastępczego „Wielkie Serce” napisało o sobie siedem rodzin, w których rodzicami są: Jan i Bożena, Marta i Zbigniew, Jadwiga i Maciej, Sylwia i Robert, Krystyna i Stanisław, Katarzyna i Mariusz, Marzena i Leszek ${ }^{90}$. Tworzą oni ze swoimi biologicznymi dziećmi (lub bez nich) i dziećmi zaadoptowanymi, przyjętymi na okres do uzyskania przez nich pełnoletności, rodziny zastępcze. Inne rodziny zastępcze współdziałają z fundacjami, np. Fundacją Archon + Dzieci Które Kochacie, Fundacją Rodzin Adopcyjnych. Tę ostatnią wymienioną fundację założyła grupa rodziców adopcyjnych, którzy przyjęli do swoich rodzin dzieci osierocone ${ }^{91}$.

Rodzin zastępczych w Polsce (różnego typu), wychowujących dzieci niczyje, niechciane, pozostawione samemu sobie, jest kilkadziesiąt tysięcy, co potwierdzają dane statystyczne. Zgodnie z danymi statystycznymi udostępnionymi przez

87 Referat w sprawie urządzania miejskiego przytuliska dla niemowląt w pałacu naramowickim, w: APP, AmP, sygn. 4111, Założenie przytuliska dla dziatwy przedszkolnej w pałacu naramowickim.

88 Pisma z dn. 7 VIII 1923 r., 12 IX 1923 r., w: APP, AmP, sygn. 4111, Założenie przytuliska dla dziatwy przedszkolnej w pałacu naramowickim.

89 Dz.U. 2011 nr 149 poz. 887.

90 Rodziny Podkarpackiego Stowarzyszenia Rodzicielstwa Zastępczego „Wielkie Serce", http://wielkieserce.org/strony/nasze-rodziny,10/ (dostęp: 2.10.2015).

91 Zob. historię Fundacji Rodzin Adopcyjnych, http://www.adopcja.org.pl/historia fundacji.php (dostęp: 3.10.2015). 
Ministerstwo Pracy i Polityki Społecznej Departament Polityki Rodzinnej można podać, że w latach 2005-2013 średnio rodzin zastępczych spokrewnionych z dzieckiem odnotowano 34 tys. takich rodzin, niezawodowych - 7,5 tys. i zawodowych 1,4 tys. $^{92}$ (zob. tabelę nr 2). Domów rodzinnych dziecka odnotowano w Polsce w roku 2012 - 228 (przebywało w nich 1476 dzieci), zaś w roku 2013 - 331 ${ }^{93}$.

Tabela nr 2. Rodziny zastępcze w Polsce (2005-2013)

\begin{tabular}{|c|c|c|c|}
\hline Lata & $\begin{array}{c}\text { Rodziny spokrewnione } \\
\text { z dzieckiem }\end{array}$ & $\begin{array}{c}\text { Rodziny } \\
\text { niezawodowe }\end{array}$ & $\begin{array}{c}\text { Zawodowe } \\
\text { rodziny zastępcze }\end{array}$ \\
\hline 2005 & 35592 & 5790 & 625 \\
\hline 2006 & 36394 & 6054 & 885 \\
\hline 2007 & 36788 & 6267 & 1102 \\
\hline 2008 & 36880 & 6326 & 1321 \\
\hline 2009 & 36762 & 6200 & 1483 \\
\hline 2010 & 36673 & 6242 & 1674 \\
\hline 2011 & 36701 & 6227 & 1843 \\
\hline 2012 & 25162 & 12162 & 1906 \\
\hline 2013 & 25842 & 12182 & \\
\hline
\end{tabular}

Źródło: Dane statystyczne za Ministerstwem Pracy i Polityki Społecznej.

Współcześnie dzieci trafiają do rodzin zastępczych czy domów rodzinnych na skutek stwierdzonych złych warunków, w których się wychowują, interwencyjnego odebrania (spowodowanego patologicznym zachowaniem opiekunów), pozostawienia dziecka w szpitalu po porodzie ${ }^{94}$, na skutek pozostawienia dziecka przez matkę w oknie życia itp. Przyczyny porzuceń dziecka przez jego matkę,

92 Statystyka, https://www.mpips.gov.pl/wsparcie-dla-rodzin-z-dziecmi/opieka-zastepcza-nad-dzieckiem/dane-statystyczne/ (dostęp: 3.10.2015).

93 Piecza Zastępcza w Polsce, http://www.rodzinawpotrzebie.org/content/view/205 /162/ (dostęp: 2.10.2015).

94 Dlaczego matki porzucają swoje dzieci?, [w:] Dzień dobry TVN, piątek 15.3.2013, http://dziendobry.tvn.pl/wideo,2064,n/dlaczego-matki-porzucaja-swoje-dzieci,79967.html (dostęp: 2.10.2015). 
podobnie jak w okresach wcześniejszych (zob. okres 1918-1939 powyżej), wynikają z przyczyn ekonomicznych, rodzinnych czy natury psychicznej. Współczesne matki pozostawiają dzieci w szpitalach, w oknach życia, ale również $\mathrm{w}$ różnych przestrzeniach miejskich (zob. tabelę $\mathrm{nr} 3$ ).

Pozostawianie dziecka w oknie życia ${ }^{95}$ od 2006 roku jest jednym ze sposobów bezpiecznego przekazania noworodka ludziom, którzy go zaadoptują, wychowają i wprowadzą w życie dorosłe. W Polsce okna życia istnieją w kilkudziesięciu miastach (jest ich ponad pięćdziesiąt na terenie III RP), np. w Krakowie prowadzone przez nazaretanki, w Poznaniu - przez Centrum Wspierania Rodziny „Swoboda”, w Gdańsku Matemblewie działające przy Domu Samotnej Mat$\mathrm{ki}^{96}$, we Wrocławiu prowadzone przez boromeuszki, w Gnieźnie przez szarytki, w Bydgoszczy przy klasztorze Mniszek Klarysek od Wiecznej Adoracji.

Tabela nr 3. Przykłady porzucania dzieci w Polsce (2011-2015)

\begin{tabular}{|c|c|c|}
\hline $\begin{array}{l}\text { Nazwa czasopisma/ } \\
\text { strony internetowej }\end{array}$ & $\begin{array}{c}\text { Data } \\
\text { (miesiąc, rok) }\end{array}$ & $\begin{array}{c}\text { Miejsce porzucenia niemowlęcia / } \\
\text { nieletniego dziecka }\end{array}$ \\
\hline $\begin{array}{l}\text { „Tygodnik } \\
\text { Ostrołęcki”a }\end{array}$ & październik 2011 & $\begin{array}{l}\text { Jednodniowa dziewczynka pozostawiona } \\
\text { przez matkę na schodach kiosku, który mie- } \\
\text { ści się na stacji PKP w Rybienku Leśnym }\end{array}$ \\
\hline $\begin{array}{l}\text { „Dziennik } \\
\text { Bałtycki”b }\end{array}$ & styczeń 2012 & $\begin{array}{l}\text { Kilkumiesięczne dziecko porzucone w po- } \\
\text { bliżu dworca PKP w Słupsku }\end{array}$ \\
\hline $\begin{array}{l}\text { „Nasze Miasto } \\
\text { Pruszcz Gdański”c }\end{array}$ & styczeń 2013 & $\begin{array}{l}\text { Nowo narodzone dziecko pozostawiła trzy- } \\
\text { dziestoletnia kobieta pod pogotowiem } \\
\text { w Pruszczu Gdańskim, o czym telefonicznie } \\
\text { poinformowała pracowników placówki }\end{array}$ \\
\hline Se.pl. ${ }^{\mathrm{d}}$ & lipiec 2014 & $\begin{array}{l}\text { Noworodek płci żeńskiej porzucony w krza- } \\
\text { kach w Iławie }\end{array}$ \\
\hline „Kurier Poranny”e & maj 2015 & $\begin{array}{l}\text { Noworodek w papierowej torbie na chodni- } \\
\text { ku na os. Leśna Dolina przez 27-letnią bia- } \\
\text { łostoczankę }\end{array}$ \\
\hline
\end{tabular}

PRZYPISY

a Matka porzuciła jednodniowe niemowlę na stacji!, „Tygodnik Ostrołęcki” 17 X 2011, http://www. to.com.pl/wiadomosci/wyszkow/art/6380210,matka-porzucila-jednodniowe-niemowle-na-stacji,id,t.html (dostęp: 9.11.2015).

95 Pierwsze w historii Europy „okno życia” zostało odnotowane w 1198 roku w Rzymie przy szpitalu Ducha Świętego z inicjatywy papieża Innocentego III.

96 D. Abramowicz, Kolęda o niechcianych Okruszkach. Historie porzucanych dzieci i ich matek, „Dziennik Bałtycki” 21 XII 2012, http://www.dziennikbaltycki.pl/artykul/724849,koleda-o-niechcianych-okruszkach-historie-porzuconych-dzieci-i-ich-matek,id,t.html?cookie $=1$ (dostęp: 9.11.2015). 
b R. Gębuś, Stupsk: Policja sprawdza, dlaczego 17-latka porzuciła dziecko, „Dziennik Bałtycki” 9 I 2012, http://www.dziennikbaltycki.pl/artykul/491923,slupsk-policja-sprawdza-dlaczego-17latka-porzucila-dziecko,id,t.html (dostęp: 9.11.2015).

c A. Cymanowska, Pruszcz Gd.: Matka zostawiła noworodka pod pogotowiem, „Nasze Miasto Pruszcz Gdański” 3 I 2013, http://pruszczgdanski.naszemiasto.pl/artykul/pruszcz-gd-matka-zostawila-noworodka-pod-pogotowiem,1675205,art,t,id,tm.html (dostęp: 9.11.2015).

c Iława: Wyrodna matka urodziła i WYRZUCIŁA noworodka w krzaki! Dziecko cudem przeżyło na tym upale!, Se.pl. 29 VII 2014, http://www.se.pl/wiadomosci/polska/wstrzasajaca-historia-z-ilawy-wyrodna-matka-wyrzucila-noworodka-w-krzaki-zdjecia_414631.html (dostęp: 9.11.2015). d Ul. Armii Krajowej. Noworodek porzucony w torbie. Matka dziecka ma dozór policji, „Kurier Poranny" 12 V 2015, http://www.poranny.pl/wiadomosci/bialystok/art/4962119,ul-armii-krajowejnoworodek-porzucony-w-torbie-matka-dziecka-ma-dozor-policji,id,t.html?cookie=1 (dostęp: 9.11.2015).

Źródło: Artykuły online.

Współcześnie (czyli w XXI w.) inkluzyjne działania na rzecz dzieci niczyich, zaniedbanych podejmują organizacje pozarządowe - sektora non-profit ${ }^{97}$. Do tych organizacji można zaliczyć fundacje, stowarzyszenia ${ }^{98}$, podmioty wyznaniowe itp. Mają one charakter typowo świecki lub kościelny. Fakt prowadzenia przez zgromadzenia zakonne okien życia, fundacji (np. Fundacji św. Jana Jerozolimskiego ${ }^{99}$ ) czy też prowadzenie przez Caritas (w II RP, III RP) akcji takich jak zbiórki żywności, pozyskiwanie datków dla dzieci z biednych rodzin i z domów dziecka potwierdza istnienie Kościoła w „dobroczynności”, pomocy bliźnim. Nadto ten typ działalności wpisuje się w koncepcję „filantropii - miłosierdzia”. Obok tej koncepcji funkcjonuje inny typ działalności - oparty o ideę świecką „filantropii - braterstwa” ${ }^{100}$. Ta idea jest realizowana przez następujące świeckie stowarzyszenia i fundacje w Polsce (na rzecz dzieci osieroconych czy dzieci niczyich): Stowarzyszenie Pomocy Mieszkaniowej dla Sierot (od

97 Szerzej specyfikę organizacji tego sektora przedstawia B. Trzaska, Rola i funkcje organizacji non-profit w gospodarce społecznej, [w:] Gospodarka społeczna w Europie, pod red. E. Pancer-Cybulskiej, Wrocław 2008, s. 259-266.

98 Więcej na temat organizacji pozarządowych - III sektora zob. w: T. Zbyrad, Miejsce i rola organizacji pozarządowych $w$ instytucjonalnym systemie pomocy rodzinie, [w:] Rodzina wobec zagrożeń, pod red. M. Dudy, Kraków 2008, s. 277-286.

99 Zob. stronę Fundacji, http://fundacjaswjana.pl/index-start.html (dostęp: 8.11.2015).

${ }^{100} \mathrm{Na}$ temat przejścia od koncepcji „filantropii - miłosierdzia” do idei „filantropii braterstwa", mającej źródło w rewolucji technicznej, zob. w: J. Montserrat, Rola redystybucji dochodowych i organizacji nonprofit $w$ Hiszpanii, „Acta Uniwersitatis Lodzienisis, Folia Oeconomica" 144 (1997), s. 255-266, zwł. 258. 
1981 roku w Baranowie k. Poznania $)^{101}$, Stowarzyszenie na rzecz Integracji i Usamodzielniania „Dom w Głogowie” ${ }^{102}$, Stowarzyszenie Pielęgniarsko-Opiekuńcze „Z Ufnością w Trzecie Tysiąclecie” ${ }^{103}$, Chrześcijańskie Stowarzyszenie Pomocy Dzieciom „Misja Nadziei”"104, Fundacja Pomocy Wdowom i Sierotom po Poległych Policjantach ${ }^{105}$, Fundacja Dzieci Niczyje ${ }^{106}$. W programowych założeniach wszystkie wyżej wymienione instytucje pozarządowe zakładają pomoc dzieciom wykluczonym społecznie na skutek porzucenia przez ich matki, osierocenia, tkwienia w skrajnej biedzie, przebywania w środowiskach patogennych na wstępie ich drogi życia. Zogniskowana praca tych organizacji na rzecz dzieci nie jest w stanie zapobiegać wszystkim potrzebom dzieci, szczególnie dzieci ulicy.

Wciąż „dzieci luźne, dzieci zagrożone, dzieci-śmieci, dzieci dworcowe” 107 itp. są obecne w Polsce. W czerwcu 2015 roku „Rzeczpospolita” podała, że dzieci ulicy w III RP jest 400 tys. ${ }^{108}$. Wśród tych dzieci lwią część stanowią dzieci popełniające czyny zabronione, takie jak: przestępstwa narkotykowe, przestępstwa o charakterze kryminalnym, rozboje, wymuszenia rozbójnicze ${ }^{109}$. Wywodzą się one ze środowisk biedy, środowisk nieprawidłowo funkcjonujących - patologicznych, z rodzin alkoholicznych, przestępczych. Życie na ulicy jest zazwyczaj ich wyborem. To tam wielu spośród nich czuje się bezpieczniej niż w domu rodzinnym czy w szkole. Od najwcześniejszych lat (w niektórych przypadkach już od 3 roku życia) uczą się sposobów przetrwania ${ }^{110}$ i dzięki temu dorastają szybciej. Faktem jest, że takie dzieci, żyjąc z dala od ośrodków opiekuńczo-wychowaw-

${ }^{101}$ Zob. informacje na temat Stowarzyszenia na stronie: http://www.spmds.org.pl/ (dostęp: 8.11.2015).

${ }_{102}$ Zob. informacje na temat Stowarzyszenia na stronie: http://www.dfop.org.pl/pl/65/ (dostęp: 8.11.2015).

${ }^{103}$ Zob. informacje na temat Stowarzyszenia i jego działalności na rzecz porzuconych noworodków, http://dzieciom.pl/opp/stowarzyszenie-pielegniarsko-opiekuncze-z-ufnoscia-w-trzecie-tysiaclecie (dostęp: 8.11.2015).

${ }^{104}$ Zob. informacje na temat udzielania pomocy dzieciom zagrożonym patologiami społecznymi, http://www.eurodesk.pl/nasza-baza/organizacja/PL0010000249.

${ }^{105}$ Zob. informacje na temat Fundacji na stronie: http://www.fundacjapolicja.pl/o-fundacji (dostęp: 9.11.2015).

${ }^{106}$ Zob. informacje na temat Fundacji, http://fdn.pl/o-fundacji (dostęp: 9.11.2015).

${ }^{107}$ Coraz więcej „dzieci ulicy”, http://wiadomosci.wp.pl/kat,1342,title,Coraz-wiecejdzieci-ulicy,wid,17666823,wiadomosc.html (dostęp: 30.09.2015).

${ }^{108}$ Coraz więcej „dzieci ulicy”, dz. cyt.

109 Zob. Tabela Czyny zabronione dzieci (lata 2000-2008), [w:] K. Biel, Przestępczość dzieci. Wczesne czynniki ryzyka i wskazówki dla skutecznej profilaktyki, [w:] Dziecko zagrożone wykluczeniem. Elementy diagnozy, działania profilaktyczne i pomocowe, pod red. K. Biela, J. Kusztal, Kraków 2011, s. 130.

${ }^{110}$ Fazy przystosowania dzieci do życia na ulicy zob. T. Szczepański (2004) Dzieci ulicy $w$ warszawskiej dzielnicy Praga-Południe jako skutek dezintegracji rodziny $i$ współczesnych 
czych i przyjmując zasady społeczności marginalnej, stają się „dziećmi luźnymi”, które „nie są przywiązane ani do rodziny, ani do szkoły, ani do żadnej instytucji odpowiedzialnej za ich opiekę i wychowanie"111. Inkluzja społeczna tej grupy dzieci jest bardzo trudna. Nie wystarcza zapewnienie tym nieletnim warunków bytowych, opiekuńczych, które mogłyby znaleźć w domach dziecka, rodzinach zastępczych - im potrzebne jest specjalistyczne wsparcie. Praca nad ich inkluzją wymaga przede wszystkim działań terapeutycznych, resocjalizacyjnych.

Problemy natury społecznej - wynikające $\mathrm{z}$ wykluczania nieletnich z życia $\mathrm{w}$ tradycyjnych rodzinach, pozbawionych podstawowych środków do egzystencji - w przestrzeni stu lat nie zostały ostatecznie rozwiązane w Polsce. Na początku zarówno XX, jak i XXI wieku noworodki były i są porzucane w różnych przestrzeniach miast, pozostawiane w oknach życia, w szpitalach (zob. tabele nr 1 i 3). Dzieci nieletnie były i są wychowywane przez ulicę, która wymusza w wielu przypadkach ich zachowania patologiczne, przestępcze.

Działalność instytucji, organizacji państwowych, społecznych, kościelnych, non profit na rzecz dzieci niechcianych, dzieci niczyich, dzieci-śmieci itp. przynosiła (w XX i początkach XXI w.) i przynosi (w XXI w.) częściowe złagodzenie niedoli tej grupy wykluczonych społecznie. Rozwój rodzin zastępczych na rzecz domów dziecka, które (zgodnie z Ustawą z dn. 9 czerwca 2011 r. o wspieraniu rodziny i systemie pieczy zastępczej) zakładają do 30 wychowanków na terenie placówki, na przestrzeni wieku pozwalają dostrzec potrzeby każdego dziecka, któremu potrzebne są nie tylko wychowanie prospołeczne i przygotowanie edukacyjne, ale również zapewnienie relacji rodzinnych, przyjacielskich. Fakt permanentnego dążenia do niesienia pomocy porzucanym dzieciom, funkcjonującym w różnych profesjach właściwych dla grup marginalnych - żebractwie, prostytucji, złodziejstwie - przez instytucje, organizacje, indywidualne osoby pozwala żywić nadzieję, że problem dzieci ulicy, dzieci-śmieci na starym kontynencie zniknie, a na innych kontynentach zostanie zredukowany.

\section{Bibliografia}

\section{Źródła archiwalne:}

Archiwum Archidiecezjalne w Poznaniu, KA 15029, Akta opieki nad dziećmi.

warunków społeczno-ekonomicznych, za: I. Pospiszyl, Patologie społeczne, Warszawa 2008, s. $309-310$.

${ }^{111}$ B. Adamczyk, Niedostosowanie społeczne dzieci ulicy w genezie zachowań dewiacyjnych i przestępczych, [w:] Dziecko zagrożone wykluczeniem..., dz. cyt., s. 213. 
Archiwum Państwowe w Gdańsku oddział w Gdyni, Starostwo Morskie w Wejherowie, sygn. 48, Opieka nad dziećmi.

Archiwum Państwowe w Poznaniu, Akta miasta Poznania

- sygn. 546, Miejski Urząd Policyjny.

- sygn. 3969, Polsko-Amerykański Komitet Pomocy Dzieciom.

- sygn. 3980, Statystyka. Opieka nad ubogimi.

- sygn. 4032, Miejski Sierociniec.

- sygn. 4033, Towarzystwo opieki nad dziećmi katolickiemi w Poznaniu.

- sygn. 4110, Dom dla matki i dziecka.

- sygn. 4111, Założenie przytuliska dla dziatwy przedszkolnej w pałacu naramowickim.

- sygn. 11007, Sprawozdania z działalności Stacji opieki nad matkq i dzieckiem.

- sygn. 11008, Dzieci podrzucone (podrzutki).

Archiwum Państwowe w Poznaniu, Miejski Urząd Bezpieczeństwa i Porządku Publicznego, sygn. 73, Zakłady opiekuńcze - Dom Jadwigi.

Archiwum Państwowe w Poznaniu, Wydział Powiatowy, sygn. 39, Wagrowiec.

Archiwum Państwowe w Kaliszu, Wydział Powiatowy w Kaliszu, sygn. 512, Domy ludowe, przytułki i ochronki.

Czasopisma:

„Dziennik Bydgoski”

„Dziennik Poznański”

„Gazeta Lwowska”

"Gazeta Międzychodzka”

„Gazeta Pleszewska”

„Kurier Poznański”

„Kurjer Wileński”

„Mały Rocznik Statystyczny” „Pielgrzym”

„Rekord Polski”

Publikacje online:

Abramowicz D., Kolęda o niechcianych Okruszkach. Historie porzucanych dzieci i ich matek, „Dziennik Bałtycki” 21 XII 2012, http://www.dziennikbaltycki.pl/artykul/724849,koleda-o-niechcianych-okruszkach-historie-porzuconych-dzieci-i-ich-matek,id,t.html?cookie=1 (dostęp: 9.11.2015).

Chrześcijańskie Stowarzyszenie Pomocy Dzieciom „Misja Nadziei”, online: http://www.eurodesk.pl/nasza-baza/organizacja/PL0010000249 (dostęp: 9.11.2015).

Coraz więcej „dzieci ulicy”, http://wiadomosci.wp.pl/kat,1342,title,Coraz-wiecej-dzieci-ulicy,wid,17666823,wiadomosc.html (dostęp: 30.09.2015).

Cymanowska A., Pruszcz Gd.: Matka zostawiła noworodka pod pogotowiem, „Nasze Miasto Pruszcz Gdański” 3 I 2013, http://pruszczgdanski.naszemiasto.pl/artykul/ 
pruszcz-gd-matka-zostawila-noworodka-pod-pogotowiem,1675205, art,t,id,tm.html (dostęp: 9.11.2015).

Dlaczego matki porzucają swoje dzieci?, [w:] Dzień Dobry TVN, piątek 15 marca 2013, http:// dziendobry.tvn.pl/wideo,2064,n/dlaczego-matki-porzucaja-swoje-dzieci,79967.html (dostęp: 2.10.2015).

Falk W., Pomoc urwisom - Dzieci ulicy, http://www.diakonia.org.pl/index.php?D=105 (dostęp: 2.10.2015).

Fundacja, http://fundacjaswjana.pl/index-start.html (dostęp: 8.11.2015).

Fundacja Dzieci Niczyje, http://fdn.pl/o-fundacji (dostęp: 9.11.2015).

Fundacja Rodzin Adopcyjnych, http://www.adopcja.org.pl/historia_fundacji.php (3.10.2015).

Fundacja Pomocy Wdowom i Sierotom po Poległych Policjantach, online: http://www.fundacjapolicja.pl/o-fundacji (dostęp: 9.11.2015).

Gębuś R., Słupsk: Policja sprawdza, dlaczego 17-latka porzuciła dziecko, „Dziennik Bałtycki” 9 I 2012, http://www.dziennikbaltycki.pl/artykul/491923,slupsk-policja-sprawdza-dlaczego-17latka-porzucila-dziecko,id,t.html (dostęp: 9.11.2015).

Wyrodna matka urodziła i WYRZUCIŁA noworodka w krzaki! Dziecko cudem przeżyło na tym upale!, Se.pl. 29 VII 2014, http://www.se.pl/wiadomosci/polska/wstrzasajaca-historia-z-ilawy-wyrodna-matka-wyrzucila-noworodka-w-krzaki-zdjecia_414631.html (dostęp: 9.11.2015).

Matka porzuciła jednodniowe niemowlę na stacji!, ,'Tygodnik Ostrołęcki” 17 X 2011, http://www. to.com.pl/wiadomosci/wyszkow/art/6380210,matka-porzucila-jednodniowe-niemowle-na-stacji,id,t.html (dostęp: 9.11.2015).

Piecza Zastępcza w Polsce, http://www.rodzinawpotrzebie.org/content/view/205/162/ (dostęp: 2.10.2015).

Program Dzieci Ulicy (program realizowany przez Fundację dla Polski), http://www.fdp.org. pl/program-dzieci-ulicy (dostęp: 2.10.2015).

Program „Dzieci Ulicy” realizowany przez Ośrodek Pomocy Społecznej w Gliwicach, http:// opsgliwice.bnet.pl/index.php/publisher/articleview/frmArticleID/138/(dostęp: 2.10.2015).

Rodziny Podkarpackiego Stowarzyszenia Rodzicielstwa Zastępczego „Wielkie Serce”, http:// wielkieserce.org/strony/nasze-rodziny,10/ (dostęp: 2.10.2015).

Staniszewska A., Ulica nie jest dla dzieci, „Niebieska Linia”. Dwumiesięcznik poświęcony problematyce przemocy, http://www.niebieskalinia.pl/pismo/wydania/dostepne-artykuly/4334-ulica-nie-jest-dla-dzieci (dostęp: 30.09.2015).

Statystyka, https://www.mpips.gov.pl/wsparcie-dla-rodzin-z-dziecmi/opieka-zastepcza-naddzieckiem/dane-statystyczne/ (dostęp: 3.10.2015).

Stowarzyszenie Pomocy Mieszkaniowej dla Sierot, http://www.spmds.org.pl/ (dostęp: 8.11.2015).

Stowarzyszenie na rzecz Integracji i Usamodzielniania „Dom w Głogowie”, http://www.dfop. org.pl/pl/65/ (dostęp: 8.11.2015).

Stowarzyszenie Pielęgniarsko-Opiekuńcze „ZUfnością w Trzecie Tysiąclecie”,http://dzieciom.pl/opp/ stowarzyszenie-pielegniarsko-opiekuncze-z-ufnoscia-w-trzecie-tysiaclecie (dostęp: 8.11.2015). 
Street and Working Children (15-25 February 1993, Florence, Italy). Summary Report, prepared by Maggie Black, http://www.unicef-irc.org/publications/pdf/igs_streetchildren. pdf (dostęp: 30.09.2015).

Ul. Armii Krajowej. Noworodek porzucony w torbie. Matka dziecka ma dozór policji, „Kurier Poranny" 12 V 2015, http://www.poranny.pl/wiadomosci/bialystok/art/4962119,ul-armii-krajowej-noworodek-porzucony-w-torbie-matka-dziecka-ma-dozor-policji,id,t. html? cookie=1 (dostęp: 9.11.2015).

\section{Opracowania:}

Adamczyk B., Adaptacyjne strategie dzieci ulicy, [w:] Dzieci ulicy. Procesy marginalizacji $i$ automarginalizacji nieletnich, pod red. K. Frysztackiego, M. Nóżki, M. Smagacz-Poziemskiej, Kraków 2011, s. 66-88.

Adamczyk B., Niedostosowanie społeczne dzieci ulicy w genezie zachowań dewiacyjnych i przestępczych, [w:] Dziecko zagrożone wykluczeniem. Elementy diagnozy, działania profilaktyczne i pomocowe, pod red. K. Biel, J. Kusztal, Kraków 2011, s. 213.

Aries P., Historia dzieciństwa, przekł. M. Ochab, Warszawa 2010.

Bauman Z., 26 grudnia 2010. O resocjalizacji socjalności, [w:] Z. Bauman, To nie jest dziennik, przekł. M. Zawadzka, Kraków 2012, s. 153-154.

Biel K., Przestępczość dzieci. Wczesne czynniki ryzyka i wskazówki dla skutecznej profilaktyki, [w:] Dziecko zagrożone wykluczeniem. Elementy diagnozy, działania profilaktyczne i pomocowe, pod red. K. Biel, J. Kusztal, Kraków 2011, s. 130.

Bołdyrew A., Sosnowska J., Troska o dziecko i jego potrzeby w działaniach Wydziału Opieki Zarządu Miasta Łodzi w okresie międzywojennym, „Kultura i Wychowanie” $2014 \mathrm{nr}$ 8, s. 21-34.

Domańska E., Wiedza o przeszłości - perspektywy na przyszłość, „Kwartalnik Historyczny” 120 (2013) nr 2, s. 221-273.

Domańska J., Dobroczynność względem sierot na ziemiach polskich do 1918 roku, „Biuletyn Historii Wychowania" 27 (2011), s. 19-31.

Geremek B., Ludzie marginesu w średniowiecznym Paryżu XIV-XV wieku, Poznań 2003.

Geremek B., „Świat opery żebraczej”. Obraz włóczęgów i nędzarzy w literaturach europejskich XV-XVII wieku, Warszawa 1989.

Glensk U., Przytułki dla dzieci w międzywojennej Polsce, [w:] Margines społeczny Drugiej Rzeczypospolitej, pod red. M. Rodaka, Warszawa 2013, s. 119-138 (Metamorfozy Społeczne, 6).

Góralski Z., Działalność charytatywna w Polsce przedrozbiorowej, Warszawa-Kraków 1973.

Grabowski A., Szpitale dziewiętnastowiecznego Poznania, [w:] Szpitale, red. J. Wiesiołowski, Poznań 2007, s. 40-46 (Kronika Miasta Poznania, 4).

Gulczyńska A., Koncepcja dziecka ulicy. Analiza z perspektywy interakcyjnej, [w:] Dzieci ulicy. Procesy marginalizacji i automarginalizacji nieletnich, pod red. K. Frysztackiego, M. Nóżki, M. Smagacz-Poziemskiej, Kraków 2011, s. 49-65. 
Jamrożek W., Problematyka opieki nad dzieckiem na kongresach i zjazdach pedagogicznych w Polsce do 1939 roku, [w:] Kongresy i zjazdy pedagogiczne w Polsce w XX wieku, pod red. A. Kicowskiej, Toruń 2001, s. 123.

Kępski C., Idea miłosierdzia a dobroczynność i opieka, Lublin 2002.

Kurzeja A., Dzieci ulicy - profilaktyka zagrożeń, Kraków 2014.

Lipiński S., Zakłady dobroczynne i domy poprawny w dawnej Polsce, Łódź 2010.

Lusting J., Skutki ubóstwa, jakich doświadczaja dzieci, [w:] Ubodzy i bezdomni, pod red. P. Dobrowolski, Katowice 1998, s. 62-78.

Łukaszewicz J., Śpitale i inne dobroczynne zakłady i fundusze, [w:] Szpitale, red. J. Wiesiołowski, Poznań 2007, s. 19-34 (Kronika Miasta Poznania, 4).

Montserrat J., Rola redystybucji dochodowych i organizacji nonprofit w Hiszpanii, „Acta Uniwersitatis Lodzienisis, Folia Oeconomica" 144 (1997), s. 255-266.

Pacanowska R., Samorząd powiatowy w Wielkopolsce w latach 1919-1939, Poznań 2006.

Piątkowska M., Życie przestępcze w przedwojennej Polsce. Gangsterzy - kasiarze - brylanty, Kraków 2012.

Pospiszyl I., Patologie społeczne, Warszawa 2008.

Prokosz M., Dziecko osamotnione i sieroce. Między rodzina pochodzenia a rodzinna forma opieki, [w:] Człowiek w sytuacji (bez)nadziei - konteksty teoretyczne i praktyczne, pod red. R. Bilik, A. Urbanka, Legnica 2011, s. 14.

Raczkowski J., Dom dziecka, [w:] Encyklopedia pedagogiczna, pod red. W. Pomykało, Warszawa 1997, s. 117.

Surdacki M., Losy dzieci porzuconych w społeczeństwie europejskim do XX wieku, [w:] Dziecko w rodzinie i społeczeństwie. Dzieje nowożytne, pod red. K. Jakubiak, W. Jamrożek, Bydgoszcz 2002, s. 155-156.

Theiss W., Pomorskie Towarzystwo Opieki nad Dziećmi 1918-1948, „Rozprawy z Dziejów Oświaty" 36 (1994), s. 173-191.

Trzaska B., Rola i funkcje organizacji non-profit w gospodarce społecznej, [w:] Gospodarka społeczna w Europie, pod red. E. Pancer-Cybulskiej, Wrocław 2008, s. 259-266.

Wigocka-Okoń B., Przedszkole, [w:] Encyklopedia pedagogiczna, pod red. W. Pomykało, Warszawa 1997, s. 636-637.

Zbyrad T., Miejsce i rola organizacji pozarządowych $w$ instytucjonalnym systemie pomocy rodzinie, [w:] Rodzina wobec zagrożeń, pod red. M. Dudy, Kraków 2008, s. 277-286. 